\title{
Risk factors of acute poisoning among children: A study at a poisoning unit of a university hospital in Egypt
}

\author{
Raed M Alazab ${ }^{1}$, Mahmoud T Elmougy ${ }^{2}$, Ramadan A Fayad ${ }^{3}$, Hoda F Abdelsalam ${ }^{4}$, Amr S Mohamed $^{5}$ \\ ${ }^{1}$ Professor of Occupational Medicine, Department of Community Medicine and Occupational Medicine; ${ }^{2,3}$ Professor of Pediatrics; \\ Faculty of Medicine, Alazhar University, Cairo, Egypt. ${ }^{4}$ Professor of Clinical Toxicology, Faculty of Medicine, Alexandria \\ University, Alexandria, Egypt. ${ }^{5}$ Specialist of Pediatrics, Ministry of Health, Alexandria, Egypt.
}

\begin{abstract}
Childhood poisoning is a major cause of morbidity in both developing and developed countries. In spite of the success of some interventions to prevent accidental poisoning in the pediatric population, toxic ingestions continue to be a common occurrence. This aim of this study was to identify the incidence rate and determinants of acute poisoning among children (1-60 months old) who were admitted to the Poisoning Unit of a university hospital in Egypt. A study was conducted in the period from July 2011 until May 2012 at the poisoning unit of a university hospital. The studied children were from both rural and urban areas, were a mix of boys and girls, did not suffer from any mental disabilities, were aged between 1 month old to 60 months old, and were of Egyptian nationality. Data was collected by using a clinical examination form and a questionnaire. All parents/carers of the studied children were interviewed as well. Clinical assessment of the children included: general health conditions; AVPU (alert, respond to verbal stimuli, respond to painful stimuli, unconsciousness); and clinical examinations. The findings of the study demonstrated that $18.5 \%$ of total admissions were children (1-60 months old), $62.5 \%$ were males, $83.3 \%$ did not attend nursery, $79.9 \%$ were from urban areas, $33 \%$ of mothers were illiterate, and $60.2 \%$ of poisonings were due to household products. Kerosene alone was implicated in $24.3 \%$ of all cases; $37.4 \%$ of cases took place in the kitchen; $47.4 \%$ of cases were poisoned during the period between $8 \mathrm{am}$ and $4 \mathrm{pm}$, and $65.4 \%$ reached the poisoning unit within 2 to 4 hours of accidental poisoning. Risk factors among the studied children were ordered by stepwise regression analysis as the following: non employed mothers; children who did not attend nursery; children of the male gender; and the education and literacy level of their mothers. Effective health promotion programs for parents and carers regarding poisoning hazards are needed to increase awareness and reduce the incidence of poisoning among children.
\end{abstract}

Keywords: Poisoning, Children, Incidence, Risk factors, Egypt.

\section{Introduction}

Poisoning can be defined as taking, or being otherwise exposed to, a substance or substances which are injurious to a person's health. ${ }^{1}$ Childhood poisoning is a major cause of morbidity in both the developing and the developed world. In spite of the success of some intervention strategies to prevent accidental poisoning in the pediatric population, toxic ingestions continue to be a common occurrence. $^{2}$

The pattern of incidence and the risk factors for children's acute poisoning change with time and differ from country to country, and even between geographical areas within the same country. ${ }^{3}$ An American survey revealed that, of the different external causes of unintentional injury and death among children aged between 1 and 14 years, poisonings ranked fourth, after road traffic crashes, fires and drowning. ${ }^{4}$ The Japan Poison Information Centre (JPIC) received 31,510 enquiries in 1995 about poisoning in children under 6 years of age; the inquiries related to children less than 1 year old were $35.7 \%$ of the cases. ${ }^{5}$ Data from the American Association of Poison Control Centers (2009) showed that children less than 6 years old made up $50.9 \%$ of cases and $2.4 \%$ of the total reported fatalities, and the most common causes of poisoning among children were due to pharmaceutical prod-

\section{Practice Points}

- Childhood poisoning is a major cause of morbidity in both developing and developed countries.

- The incidence rate of acute poisoning among children (1-60 months old) was $18.5 \%$ with a male predominance of $62.5 \%$.

- Kerosene alone was implicated in $24.3 \%$ of all cases; $37.4 \%$ of cases took place in the kitchen; $47.4 \%$ of cases were poisoned during the period between $8 \mathrm{am}$ and $4 \mathrm{pm}$, and $65.4 \%$ reached the poisoning unit within 2-4 hours of poisoning.

- Risk factors in children were non employed mothers; children who did not attend nursery; children of the male gender; and the education and literacy level of their mothers.

- Effective health promotional programs for parents and carers regarding poisoning hazards are needed to increase the awareness and reduce the incidence of poisoning among children.

Correspondence: Dr. Raed M Alazab, Professor of Occupational Medicine at Department of Community Medicine and Occupational Medicine, Faculty of Medicine, Alazhar University, Cairo, Egypt. E-mail: raedelazab@hotmail.com.

South East Asia Journal of Public Health 2012;2(2):41-47. (C) 2012 Alazab et al., publisher and licensee Public Health Foundation Bangladesh. This is an Open Access article which permits unrestricted non-commercial use, provided the original work is properly cited. 
ucts. $^{6}$ An estimated 86,000 childhood poisoning incidents were treated in US hospital emergency departments in 2008, amounting to 429.4 poisonings per 100,000 children. $^{7}$ Various studies have identified kerosene, petrol, medicines, insecticides, and household cleaning products as major hazards for poisoning incidents among young children. ${ }^{3,8}$

Poisoning can have long-term psychological and physical consequences for children, and may result in large societal costs. In low- and middle-income countries, poisoning accounts for $10 \%$ of the total burden of unintentional injuries, and $6 \%$ of disability adjusted life years. ${ }^{9}$ Unfortunately, much of the country-specific information is from high-income countries. Some lowand middle-income countries have established poison control centers and begun to conduct research on poisonings. ${ }^{6}$ Although there are educational programs and public campaigns designed to prevent children's acute poisoning, it continues to be a common medical emergency in the pediatric population. ${ }^{4}$ Despite advances such as childproof caps on medication bottles, childproof packaging, increased educational efforts, and increased awareness of commonly ingested substances, deaths due to unintentional poisonings still occur. ${ }^{7}$ This study will try to identify the incidence rate and determinants of acute poisoning among children (1-60 months old) who were admitted to the Poisoning Unit of a university hospital in Egypt.

\section{Materials and methods}

\section{Research setting}

The present study was conducted in a Poisoning Unit at a University Hospital in Egypt. This unit of poisoning is the main centre in the governorate, where any poisoning case that needs consultation is referred to.

\section{Study design}

A study was conducted in the period from July 2011 until May, 2012. This study was conducted in three phases. Phase 1: three months preparatory phase (during which site of the study, target population, preparation of interview sheet, pilot study, sampling and ethical consideration were done); phase 2: three months implementation phase (during which data collection, diagnosis, treatment, and follow up till reaching the outcome of the case) were conducted; and Phase 3: five months evaluation phase (during which data entry, statistical analysis, results, discussion, conclusion and recommendations were formulated).

\section{Target population and Sampling}

All children from both rural and urban areas who were admitted to the examined poisoning unit during the implementation phase of the present study (3 months) were included in the present study. Others inclusion criteria were: boys and girls, not suffering from any mental disabilities, aged between 1 month old and 60 months old, and of Egyptian nationality.

\section{Data Collection}

Data was collected by using an examination form (containing personal history, complaint, present history, past history, family history, general examination, local examination, investigations, and final diagnosis) and a questionnaire (demographic data, causes of poisoning, risk factors of poisoning, route and type of poisoning). All parents/carers of the studied children were interviewed.

Clinical assessment of the children included: general health conditions; AVPU (alert, response to verbal stimuli, response to painful stimuli, unconsciousness); and clinical examinations (temperature, pulse rates, blood pressure, mouth ulcers/corrosions/cyanosis, skin color changes, pupil dilation, respiratory rates, signs of respiratory distress and CNS manifestations).

Regular evaluation of the patient suspected of an overdose was essential for identifying new or developing findings or toxic syndromes, and for early identification and treatment of a deteriorating condition. This was done until the patient recovered completely, or was considered to no longer be at risk of the consequences of a toxic exposure. Estimation of vital signs was recorded every 4 hours. The following tests were done to confirm the diagnosis or initiate treatments: ECG for cases with digitalis intoxication; chest radiographs for all cases involving corrosive poisons, as well as kerosene and other related petroleum distillates; ultrasound and/or CT scans for selected cases; arterial blood gases routinely for all cases involving household products, drugs and narcotic related acute poisoning; urea, creatinine, transaminases, PT, PTT, INR, CBC and serum electrolytes for all cases admitted to the ICU; random blood glucose tests for cases poisoned with overdoses of ingested oral hypoglycemic drugs, as well as all ICU patients; serum tegretol level for tegretol toxicity; serum digoxin concentration for digitalis toxicity; serum theophylline level for theophylline toxicity; and viva color test for the cases of accidental ingestion of unknown drugs.

\section{Statistical analysis}

Data entry and statistical analysis were done by using the Epi Info program (3.2.2 version, CDC, USA). Proportion, mean $\pm \mathrm{SD}$, and stepwise regression analysis were the statistical methods used in analysis of obtained data.

\section{Ethical consideration}

All administrative approvals were taken from the administrative team of the hospital including the managing director and the head of the departments. All parents/carers of the examined children were subjected to a brief description on the aim of the study and oral consent was taken from them before the inclusion of their children into the present study. 


\section{Results}

During the study period, $18.5 \%(n-437)$ of the total admitted cases (n-2358) in the Poisoning Unit were children aged 1-60 months (Mean \pm Std: 29.5 \pm 12.2 ). Among 437 children, $273(62.5 \%)$ cases were males and $349(79.9 \%)$ children were from urban areas. The age range of mothers and fathers was 17-44 years (mean \pm Std: $28.03 \pm 4.4$ ) and $19-53$ years (mean \pm Std: $34.4 \pm 6.2$ ) respectively. The working hours of mothers and fathers was 6-8 hours/day (mean \pm Std: $6.08 \pm 0.4$ ) and 6-12 hours/day (mean \pm Std: $7.2 \pm 2.05$ ) respectively. The number of members in the family is between 3 to 10 (mean \pm Std: $5.04 \pm 2.2$ ). The other socio-demographic characteristics of the studied children and their parents are shown Table 1.

Table 2 shows routes of poisoning; $99.3 \%$ of the poisonings occurred via oral routes. Household products were shown to be the leading causative agents $(60.2 \%)$ for acute poisoning in the present study - kerosene alone was implicated in $106(24.3 \%)$ cases. Cleaning products (chlorine, detergents) were the next common household products $-64(14.6 \%)$ cases were due to

Table 1: Socio-demographic characteristics of the studied children and their parents

\begin{tabular}{|c|c|}
\hline Characteristics & $\begin{array}{c}\text { Respondents }(\%) \\
(n-437)\end{array}$ \\
\hline $\begin{array}{l}\text { Child Gender } \\
\text { Male } \\
\text { Female }\end{array}$ & $\begin{array}{c}273(62.5 \%) \\
164(37.5 \%)\end{array}$ \\
\hline $\begin{array}{l}\text { Child Residency } \\
\text { Rural } \\
\text { Urban }\end{array}$ & $\begin{array}{c}88(20.1 \%) \\
349(79.9 \%)\end{array}$ \\
\hline $\begin{array}{l}\text { Child education } \\
\text { Attending nursery }\end{array}$ & $73(16.7 \%)$ \\
\hline $\begin{array}{l}\text { Employment status - mothers } \\
\text { Working }\end{array}$ & $46(10.5 \%)$ \\
\hline $\begin{array}{l}\text { Educational level - mothers } \\
\text { Illiterate } \\
\text { Read and write } \\
\text { Primary school } \\
\text { Prep school } \\
\text { Secondary school } \\
\text { University }\end{array}$ & $\begin{array}{c}90(20.6 \%) \\
54(12.4 \%) \\
39(8.9 \%) \\
36(8.2 \%) \\
137(31.4 \%) \\
81(18.5 \%)\end{array}$ \\
\hline $\begin{array}{l}\text { Employment status - fathers } \\
\text { Working }\end{array}$ & $420(96.1 \%)$ \\
\hline $\begin{array}{l}\text { Educational level - fathers } \\
\text { Illiterate } \\
\text { Read and write } \\
\text { Primary school } \\
\text { Prep school } \\
\text { Secondary school } \\
\text { University }\end{array}$ & $\begin{array}{c}61(14 \%) \\
75(17.2 \%) \\
20(4.6 \%) \\
35(8 \%) \\
152(34.7 \%) \\
94(21.5 \%)\end{array}$ \\
\hline $\begin{array}{l}\text { Carer during accident } \\
\text { Mother } \\
\text { Others }\end{array}$ & $\begin{array}{c}386(88.3 \%) \\
51(11.7 \%)\end{array}$ \\
\hline $\begin{array}{l}\text { Family type } \\
\text { Simple } \\
\text { Compound }\end{array}$ & $\begin{array}{c}381(87.2 \%) \\
56(12.8 \%)\end{array}$ \\
\hline
\end{tabular}

Table 2: Route and type of poisons among the studied children

\begin{tabular}{|c|c|}
\hline Route and types & $\begin{array}{c}\text { Respondents (\%) } \\
(\mathrm{n}-437)\end{array}$ \\
\hline $\begin{array}{l}\text { Route of exposure to poison } \\
\text { Oral } \\
\text { Dermal } \\
\text { Respiratory }\end{array}$ & $\begin{array}{c}434(99.3 \%) \\
2(0.5 \% \\
1(0.2 \% \\
\end{array}$ \\
\hline $\begin{array}{l}\text { Type of poisoning } \\
\text { Household product } \\
\text { Kerosene } \\
\text { Cleaning products } \\
\text { Chlorine } \\
\text { Others } \\
\text { Pesticides } \\
\text { - Insecticides } \\
\text { - Others } \\
\text { Caustic potash } \\
\text { Disinfectants } \\
\text { Others }\end{array}$ & $\begin{array}{c}263(60.2 \%) \\
106(24.3 \%) \\
74(16.9 \%) \\
64(14.6 \%) \\
10(2.3 \%) \\
59(13.5 \%) \\
52(11.9 \%) \\
7(1.6 \%) \\
9(2.1 \%) \\
8(1.8 \%) \\
7(1.6 \%)\end{array}$ \\
\hline $\begin{array}{l}\text { Drugs } \\
\text { Antiepileptic/Anticonvulsant } \\
\text { Analgesics } \\
\text { Oral contraceptive pills } \\
\text { Cough medication } \\
\text { Antihypertensive tablets } \\
\text { Digoxin tablets } \\
\text { Unknown drug } \\
\text { Others (different medicines) }\end{array}$ & $\begin{array}{l}102(23.3) \\
15(3.4 \%) \\
12(2.7 \%) \\
10(2.3 \%) \\
6(1.4 \%) \\
7(1.6 \%) \\
5(1.1 \%) \\
5(1.1 \%) \\
42(9.6 \%)\end{array}$ \\
\hline Food poisoning & $55(12.6 \%)$ \\
\hline $\begin{array}{l}\text { Others (Unknown substance, } \\
\text { snake bite, mercury, castor } \\
\text { seed etc.) }\end{array}$ & $17(3.9 \%)$ \\
\hline
\end{tabular}

chlorine. Drugs were responsible for 102 (23.3\%) cases; the most common drug was found to be anticonvulsants, ingested by $15(3.4 \%)$ children. Pesticides accounted for $59(13.5 \%)$ cases, and food poisoning was implicated in $55(12.6 \%)$ cases.

Table 3 shows that $47.4 \%$ of cases were poisoned during the period of time between 8 am and $4 \mathrm{pm}$ and $163(37.3 \%)$ cases were poisoned between $4 \mathrm{pm}$ and 12 am. About $65 \%$ of cases reached the poisoning unit within 2 to 4 hours of accidental poisoning, while $24 \%$ of cases reached there within 4 to 6 hours. Approximately $90 \%$ of cases were poisoned in their parent's house, with $37 \%$ of accidents taking place in the kitchen. It was shown that $317(72.5 \%)$ cases of poisoned children were affected from reachable sources (at a height of 150 centimeters from floor); in 198 $(57.2 \%)$ cases containers were locked, but in 197 $(45.1 \%)$ cases, it was revealed that the poison was not in its original container.

Table 4 shows details clinical findings of the children; $54.6 \%$ cases were ill and $363(83.1 \%)$ cases were alert with regards to their AVPU score. 
Table 3: Time, place, location, availability and container of poisons among the studied children

\begin{tabular}{|l|c|}
\hline $\begin{array}{l}\text { Time, place, location, availability } \\
\text { and container of poison }\end{array}$ & $\begin{array}{c}\text { Respondents } \\
(\mathbf{\%}) \\
(\mathrm{n}-437)\end{array}$ \\
\hline $\begin{array}{l}\text { Time of exposure } \\
\text { 8am - 4pm }\end{array}$ & $207(47.4 \%)$ \\
4pm - 12am & $163(37.3 \%)$ \\
12am - 8am & $67(15.3 \%)$ \\
\hline Time of consultation & $14(3.2 \%)$ \\
Less than 2 hours & $286(65.5 \%)$ \\
2-4 hours & $105(24 \%)$ \\
$4-6$ hours & $32(7.3 \%)$ \\
More than 6 hours & $390(89.2 \%)$ \\
\hline Place of poisoning & $16(3.7 \%)$ \\
Parent's house & $31(7.1 \%)$ \\
Grandparent's house & \\
Others & \\
\hline $\begin{array}{l}\text { Location of poisoning } \\
\text { (cases other than food poisoning; }\end{array}$ & \\
n-382) & $143(37.4 \%)$ \\
Kitchen & $91(23.8 \%)$ \\
Bedroom & $67(17.5 \%)$ \\
Bathroom & $3(0.8 \%)$ \\
Garden & $78(20.4 \%)$ \\
Others* & $317(72.5 \%)$ \\
\hline Reach ability of poison & $50(11.4 \%)$ \\
Reachable (150cm from floor) & \\
Not reachable ( $>50 \mathrm{~cm}$ from floor) & $198(57.2 \%)$ \\
Others & $149(42.8 \%)$ \\
\hline Type of containers & $197(45.1 \%)$ \\
No container & \\
Original & \\
Not original & \\
\hline Status of observed containers (n- \\
346) & \\
Locked & \\
Unlocked & \\
\hline
\end{tabular}

*Living room, dining room, balcony \& unknown place.

As per treatment modalities, gastric lavage was done for $164(37.5 \%)$ cases, IV fluids were given to 152 $(34.8 \%)$ cases, and $127(29.1 \%)$ cases did not take any medicines; $125(28.6 \%)$ cases were given $\mathrm{H}_{2}$ blockers and corticosteroids, whereas $35(8 \%)$ cases were given $\mathrm{H}_{2}$ blockers, antiemetics, antispasmodics, and metronidazole.

More than $67 \%$ of cases were discharged from hospital within 6 hours, while $116(26.5 \%)$ cases were discharged within 6 to 12 hours. $27(6.2 \%)$ cases were discharged after 12 hours. The majority of cases $(97 \%)$ recovered, while $13(3 \%)$ cases were referred to the ICU, where they remained until their recovery. No children died during the study period.

The stepwise regression analysis in Table 5 shows the order of the risk factors of acute poisoning among the studied children: children of mothers who were not
Table 4: Clinical examinations of the studied children

\begin{tabular}{|c|c|}
\hline Clinical Examinations & $\begin{array}{c}\text { Respondents } \\
(\%) \\
(\mathrm{n}-437) \\
\end{array}$ \\
\hline $\begin{array}{l}\text { General condition } \\
\text { Healthy } \\
\text { Ill } \\
\text { Distressed } \\
\text { Drowsy } \\
\text { Comatose }\end{array}$ & $\begin{array}{c}104(23.8 \%) \\
239(54.6 \%) \\
20(4.6 \%) \\
63(14.4 \%) \\
11(2.6 \%)\end{array}$ \\
\hline $\begin{array}{l}A V P U \\
\text { A:Alert } \\
\text { V:Respond to verbal stimuli } \\
\text { P:Respond to painful stimuli } \\
\text { U:Unconscious }\end{array}$ & $\begin{array}{c}363(83.1 \%) \\
50(11.4 \%) \\
13(3 \%) \\
11(2.5 \%) \\
\end{array}$ \\
\hline $\begin{array}{l}\text { Respiratory rate } \\
\text { Normal } \\
\text { Tachypnea } \\
\text { Bradypnea (respiratory rate }<20 \text { ) }\end{array}$ & $\begin{array}{c}414(94.7 \%) \\
22(5.1 \%) \\
1(0.2 \%)\end{array}$ \\
\hline $\begin{array}{l}\text { Pulse } \\
\text { Normal } \\
\text { Abnormal }\end{array}$ & $\begin{array}{c}437(100 \%) \\
0\end{array}$ \\
\hline $\begin{array}{l}\text { Temperature } \\
\quad \text { Normal } \\
\text { Fever }(>37.5) \\
\end{array}$ & $\begin{array}{c}416(95.2 \%) \\
21(4.8 \%) \\
\end{array}$ \\
\hline $\begin{array}{l}\text { Blood pressure } \\
\text { Normal } \\
\text { Hypotension }\end{array}$ & $\begin{array}{c}432(98.9 \%) \\
5(1.1 \%)\end{array}$ \\
\hline $\begin{array}{l}\text { Mouth } \\
\text { Ulcers and corrosions } \\
\text { Nothing } \\
\text { Redness around mouth }\end{array}$ & $\begin{array}{c}11(2.5 \%) \\
381(87.2 \%) \\
45(10.3 \%) \\
\end{array}$ \\
\hline $\begin{array}{l}\text { Skin } \\
\text { Free } \\
\text { Red } \\
\text { Cyanosis }\end{array}$ & $\begin{array}{c}434(99.3 \%) \\
2(0.5 \%) \\
1(0.2 \%) \\
\end{array}$ \\
\hline $\begin{array}{l}\text { Pupil } \\
\text { Reactive } \\
\text { Pin point pupil }\end{array}$ & $\begin{array}{c}433(99.1 \%) \\
4(0.9 \%)\end{array}$ \\
\hline $\begin{array}{l}\text { Signs of respiratory distress } \\
\text { Yes } \\
\text { No }\end{array}$ & $\begin{array}{c}20(4.6 \%) \\
417(95.4 \%)\end{array}$ \\
\hline $\begin{array}{l}\text { Central nervous system } \\
\text { Free } \\
\text { Convulsions } \\
\text { Hallucinations }\end{array}$ & $\begin{array}{c}432(98.8 \%) \\
3(0.7 \%) \\
2(0.5 \%)\end{array}$ \\
\hline
\end{tabular}

employed (housewives), children who were not attending nursery, children of the male gender, and, lastly, the education and literacy level of the mothers.

\section{Discussion}

Acute poisoning is one of the most prominent causes of emergency unit admissions. Identification and documentation of epidemiological aspects and other variables in childhood poisoning are of great importance for the determination of proper preventive measures. In the present study, acute poisoning accounted for $18.5 \%$ of the cases admitted to the examined toxicology unit. Studies conducted by Andiran \& Sarikayalar ${ }^{12}$ in Turkey found that, out of 489 poisoning cases, the majority 
Table 5: Stepwise regression analysis of risk factors of acute poisoning among the studied children

\begin{tabular}{|l|c|c|}
\hline Risk factors & B-Coefficient & $\begin{array}{l}\text { Partial } \\
\text { F test }\end{array}$ \\
\hline $\begin{array}{l}\text { Not employed mothers } \\
\text { (housewives) }\end{array}$ & -0.0053 & 2.9 \\
\hline $\begin{array}{l}\text { Children not attending } \\
\text { nursery }\end{array}$ & -0.0094 & 1.8 \\
\hline Male gender & -0.0032 & 1.5 \\
\hline $\begin{array}{l}\text { Illiterate and only read } \\
\text { and write mothers }\end{array}$ & -0.0015 & 1.2 \\
\hline
\end{tabular}

of the victims under 10 years of age were male, whereas most of the victims over 10 years of age were female. In several studies, it has been reported that $51.4 \%-73.3 \%$ of all poisoning cases observed in Turkey involved children $<5$ years of age. ${ }^{10-13}$

It was observed that in developed countries, the percentage of pediatric emergency service admissions for poisoning was between $0.28 \%$ and $0.66 \%{ }^{8-15}$. According to these findings, it is postulated that poisonings are still an important issue in Egypt (very low proportion in developed countries when compared to the proportion of the present study). The male predominance $(62.5 \%)$ of poisoning in this study was also supported by studies conducted in Pakistan ${ }^{1}$ and in Kuwait. ${ }^{14}$ This could be explained as males are more active than females, less obedient to their parents orders, and are more likely to explore world around them.

Ozdogan et al. ${ }^{13}$ found that the highest incidences of poisoning occurred in children in the age group of 13 months to 4 years. In this age group, putting small foreign objects like drugs into mouth by children can cause poisoning. In the present study, $99.3 \%$ of the studied cases were poisoned through oral routes and $23.3 \%$ of all poisonings were due to drugs. This may be due to placing the drug in easily accessible places.

It was also found in the present study that $24.3 \%$ of the studied cases were poisoned by kerosene. Kerosene oil is the most common hazardous substance ingested accidentally by children living in developing countries like Pakistan, ${ }^{1}$ India, ${ }^{16}$ and Sri Lanka, ${ }^{17}$ most likely due to their inquisitive behavior. Surprisingly, in this era of social and technological development, kerosene poisoning cases are still reported from industrialized countries. $^{3}$ The toxic effects on the body are a result of its chemical properties: it is more aromatic, has a lower viscosity, as well as a lower surface tension. It was reported in an Iraqi study $^{18}$ that, for children below 5 years, the most prominent causes of death through poisoning were hydrocarbons, again mainly kerosene $(56.2 \%)$, followed by drugs, then insecticides, household products, carbon monoxide, and rat poison. Other studies in Kuwait, ${ }^{14,19}$ Pakistan, ${ }^{20}$ Austria, ${ }^{21}$ and India ${ }^{22}$ have also implicated kerosene as a major cause of acute poisoning among children below 5 years old. However, studies conducted in the United Arab Emirates, ${ }^{23}$ Oman, ${ }^{24}$ Turkey, ${ }^{12}$ and Greece ${ }^{25}$ found drugs to be the major cause of poisoning in children. This could be referred to changes in habits and lifestyles, beside improvements in the socioeconomic state. Also, the type of drug reflects the common drugs used in each community.

In the present study, it was noted that the urban environment is more hazardous, and this could be explained by the increased availability and use of poisonous substancesover rural areas. It was also found that the mean number of capita per the studied families was 5.04 which is consistent with the findings of Azizi et $a .^{26}$ and and Ozdogan et al. ${ }^{13}$ from Turkey.

It was reported in the present study that mean age of the mothers of the affected children was 28.03 years. This corresponds to the findings of a study conducted in Iraq $^{18}$ which found that most accidental poisoning cases occurred in children with mothers aged 25-35 years. In the present study, the children of working mothers were at a lower risk of poisoning than those of housewives. This finding is in line with Chatantiprapa et al. ${ }^{27}$ from Thailand and from Burkina Faso. ${ }^{28}$ Housewife mothers provide inadequate supervision to their children and can inadvertently create a hazardous home environment due to unhealthy storage habits. ${ }^{25}$ Contrary to that, working mothers often leave their children in a selected environment (such as a nursery) with chosen supervisors. This was evident in the present study as the majority of the poisoned children did not attend a nursery. These findings confirm the significance of adequate and appropriate supervision, as well as a safe environment as a way to reduce the risks of exposing children to poisonous substances. Also, the amount of time the mothers spent with their children was not found to be as important as what a mother brings to the relationship with the child. On average, these employed mothers are working for about 6 hours per day, but it could be postulated that they spend more time with their children on days off, and less time on household chores, leisure and other activities, thus helping keep children away from poisons.

In the present study, the highest frequency of cases of poisoning was noticed at between 8 am and 4 pm followed by the period between $4 \mathrm{pm}$ and 12am (Table 3 ). This confirms that the working status of the mothers is not a direct cause of the accidents of poisoning among the studied children, as a majority of the accidents occurred during a time that employed mothers would be at work, but unemployed mothers would still be at home (with the present study revealing that $89.5 \%$ of the admitted cases were children of unemployed mothers). This agrees with a study conducted in Iraq $^{18}$ which found that the highest frequency of poisoning cases was noticed at between $8 \mathrm{am}$ and $12 \mathrm{pm}$ followed by the times between $12 \mathrm{pm}$ and $4 \mathrm{pm}$.

It was found in the present study that the majority of cases who were admitted to the poisoning unit were alert with normal signs and very few symptoms of poisoning (e.g. normal respiratory rate, pulse rate, tempera- 
ture, blood pressure etc.). It was also demonstrated that the most of the toddlers were usually presented for evaluation within $2-4$ hours, with $97 \%$ of cases were recovering, and no fatalities occurring during the period of the study. This could be attributed to the fact that acute poisoning among the studied children was unintentional (not suicidal) and the amount taken by the children usually small.

\section{Conclusion}

The incidence rate of acute poisoning among children (1 -60 months old) was $18.5 \%$ with a male predominance of $62.5 \%$. Kerosene alone was implicated in $24.3 \%$ of all cases and $37.4 \%$ of cases took place in the kitchen. No fatalities were reported. Risk factors among the studied children were ordered by stepwise regression analysis and identified children of unemployed mothers (housewives), children who did not attend nursery, children of the male gender, and the educational level of mothers. Effective health promotional programs for parents and carers regarding poisoning hazards are needed to increase the awareness and reduce the incidence of poisoning among children.

\section{References}

1. Ahmed B, Fatmi Z, Siddiqui AR, Sheikh AL. Predictors of unintentional poisoning among children under 5 years of age in Karachi: a matched case control study. Inj Prev 2011;17:1727.

2. CDC. Poisoning among children - United States. MMWR 2010;33:129-31.

3. Lawson GR, Craft AW, Jackson RH. Changing pattern of poisoning in children in Newcastle. $\mathrm{Br}$ Med J (Clin Res Ed) 1983;287:15-7.

4. Walton WW. An evaluation of the Poison Prevention Packaging Act. Pediatrics 1982;69:36370 .

5. Goto K, Fredrick H, Hamsertksa M, Flksadert N. Poisoning in children in Japan. Indian J Pediatr 1997;64:461-8.

6. Bronstein AC, Spyker DA, Cantilena LR Jr, Green JL, Rumack BH, Dart RC. 2010 Annual Report of the American Association of Poison Control Centers' National Poison Data System (NPDS): 28th Annual Report. Clin Toxicol (Phila) 2011;49:910-41.

7. Marchelet S and Leiller H. Epidemiology of serious poisonings. Clin Toxicol Rev 2009;5:1117.

8. Mintegi S, Fernández A, Alustiza J, Canduela V, Mongil I, Caubet I, et al. Emergency visits for childhood poisoning: a 2-y prospective multicenter survey in Spain. Pediatr Emerg Care 2006; 22:334-8.
9. Taft C, Volkaner M, Sarmerick S, Freick N. Childhood unintentional injury worldwide: meeting the challenge. American Pediatr Emerg Care. 2010;21:248-51.

10. Mutlu M, Cansu A, Karakas T, Anglack H. Pattern of pediatric poisoning in the east Karadeniz region between 2002-2006: increased suicide poisoning. Hum Exp Toxicol 2010;29:131 -6 .

11. Bicer S, Sezer S, Cetindag F, Mackersen L. Evaluation of acute intoxications in pediatric emergency clinic in 2005. Marmara Medical $J$ 2007;20:12-20.

12. Andiran N, Sarikayalar F. Pattern of acute poisonings in childhood in Ankara: what has changed in twenty years? Turk $J$ Pediatr 2004;46:147-52.

13. Ozdogan H, Davutoglu M, Bosnak M, Tutanc M, Haspolat K. Pediatric poisonings in southeast of Turkey: epidemiological and clinical aspects. Hum Exp Toxicol 2008;27:45-8.

14. Akhtar S, Rani GR, Al-Anezi F. Risk Factors in Acute Poisoning in Children: A Retrospective Study. Kuwait Med J 2006;38:33-6.

15. Burillo-Putze G, Munne P, Dueñas A, Bancklerthem K. National multicentre study of acute intoxication in emergency departments of Spain. Eur J Emerg Med 2003;10:101-4.

16. Babar MI, Bhait RA, Cheema ME. Kerosene oil poisoning in children. J Coll Physicians Surg Pak 2002;12:472-6.

17. Fernando R, Fernando DN. Childhood poisoning in Sri Lanka. Indian J Pediatr 1997;64:457-60.

18. Baaker RH. Risk Factors for Childhood Poisoning: A Case - Control Study in Baghdad. MMJ 2010;9:6-12.

19. Motlagh MS, Nazari Z. Epidemiologic evaluation of acute poisoning between children in Amir kabir and Abuzar Hospitals in year 2000. Scientific J Forensic Med Autumn 2002;27:39-42.

20. Assar S, Hatami S, Lak E, Pipelzadeh M, Joorabian M. Acute poisoning in children. Pak J Med Sci 2009;25:51-4.

21. Korninger HC, Lenz K. Poisoning in childhoodan information centre report. Wien KlinWochenschr 1978; 901-7.

22. Gupta SK, Peshin SS, Srivastava A, Kaleekal T. A study of childhood poisoning at national poisons information center, all india institute of medical science, New Delhi. J Occup. Health 2003;45:191-6. 
23. Dawson KP, Harron D, McGrath L, Amirlak I, Yassin A. Accidental poisoning of children in the United Arab Emirates. Eastern Mediterranean Health $J$ 1997;3:38-42.

24. Hanssens Y, Deleu D, Taqi A. Etiology and demographic characteristics of poisoning: a prospective hospital based study in Oman. Clin toxicol 2001;39:371-80.

25. Petridou El, Kouri N, Polychronopoulou A, Siafas K, Stoikidou M, Trichopoulos D. Risk factors for childhood poisoning: a case-control study in Greece. Inj Prev 1996;2:208-11.
26. Azizi BH, Zulkifli HI, Kasim MS. Risk factors for accidental poisoning in urban Malaysian children. Ann Trop Paediatr 1993;13:183-8.

27. Chatantiprapa K, Chokkanapitak J, Pinpradit N. Host and environmental factors for exposure to poisons: a case control study of preschool children in Thailand. Inj Prev 2001;7;214-7.

28. Kouéta F, Dao L, Yé D, Fayama Z, Sawadogo A. Acute accidental poisoning in children: Aspects of their epidemiology, aetiology, and outcome at the Charles de Gaulle Paediatric Hospital in Ouagadougou (Burkina Faso). Santé 2009;19:559. 